
\section{Theoretical \& Applied Science}

\author{
p-ISSN: 2308-4944 (print) e-ISSN: 2409-0085 (online) \\ Year: 2015 Issue: 10 Volume: 30 \\ Published: $30.10 .2015 \quad$ http://T-Science.org
}

Abdullo Abduhalilov

Senior Lecturer, Faculty of social sciences The Mirzo Ulugbek National University of Uzbekistan naumenko06@mail.ru

SECTION 24. Sociological research.

\title{
FEATURES MODERNIZATION OF SOCIETY IN THE EAST
}

Abstract: In this article the author on the basis of modern concepts of modernization has revealed features of modernization processes in the countries of the East. On the basis of a comparative analysis of models of various countries of the East the author came to the conclusion that an important aspect of modernization is the formation of an effective government.

Key words: modernization, development, East, model, government, public administration, Westernization, civilization, culture, progress, good governance.

Language: Russian

Citation: Abduhalilov A (2015) FEATURES MODERNIZATION OF SOCIETY IN THE EAST. ISJ Theoretical \& Applied Science 10 (30): 75-78.

Soi: http://s-o-i.org/1.1/TAS-10-30-18 Doi: crossef http://dx.doi.org/10.15863/TAS.2015.10.30.18

\section{ОСОБЕННОСТИ МОДЕРНИЗАЦИИ ОБЩЕСТВА В СТРАНАХ ВОСТОКА}

Аннотация: В данной статье автор на основе современных концепций модернизации выявил особенности модернизационных процессов в странах Востока. На основе сравнительного анализа моделей различных стран Востока автор пришел к выводу, что важныл аспектом модернизачии является формирование эффективного государственного управления.

Ключевые слова: модернизащия, развитие, Восток, модель, государство, государственное управление, вестернизация, цุивилизация, культура, прогресс, эффективное управление.

Сегодня процессы модернизации обретают необратимый и глобальный характер, поскольку создаются универсальные модели и методы модернизации общества. Но вместе с тем независимо от моделей мы можем наблюдать и специфические аспекты модернизации, которые не всегда поддаются классическим методам анализа данного процесса. В основном, это относится к странам Востока, которые, несмотря на существующие универсальные принципы модернизации, изменялись исходя из собственных условий. Анализ процессов модернизации в странах Востока является актуальным не только для стран с восточной культурой, которое в настоящее время стоят на пороге серьезных политических и социальноэкономических изменений, но и для стран Западной Европы и США, поскольку наблюдается динамичный рост значимость стран Азиатско-Тихоокеанского региона (АТР) в мировой экономической системе. Эксперты прогнозируют, что роль данного региона в перспективе будет возрастать и международный бизнес все больше будет концентрироваться в странах АТР [1].

Для более глубокого понимания специфики восточных модернизационных процессов необходимо кратко описать фундаментальные концепции собственно модернизации, возникшие в 60-70-е года XX века, поскольку именно тогда происходит пробуждение стран Востока и теории, возникшие в это время серьезно ощутили влияние процессов, происходивших в таких странах, как Япония, Республика Корея, Сингапур, Китай и др.

В 60-70-е года XX века начинается серьезная критика концепций модернизации как с позиций теории, так и сторонниками эмпирических подходов. Это было связанно с тем, что первоначальные утверждения теоретиков модернизации противоречили фактам в теоретической и практической плоскостях. Ученые того времени указывали на ошибочность прямого противопоставления традиций и современности. Здесь необходимо отметить, что модернизация может усиливать традиции. Так 
традиционные формы лидерства могут оказаться неотъемлемой частью процессов модернизации. Например, это можно было наблюдать в начале XX века в Турции, где Кемаль Ататюрк был основным инициатором социально политических реформ проведенных в стране. Несмотря на мощную критику теорий модернизации во второй половине 80-х годов формулируются новые теории модернизации в обход «модерните». В этих теориях процессы модернизации рассматриваются без серьезной ломки традиций и жесткой вестернизации. Иное осмысление концептуальных основ модернизации происходит благодаря работам таких ученых как А.Абдельмалек, А.Турен, Ш.Эйзенштад и др. Как отмечал А.Турен, в последнее время процессы модернизации опровергли либерально универсалистский рационализм, который полагал, что модернизация должна осуществляться самим разумом на основе наук, технологий и системы образования. Взамен этому, по мнению А.Турена, приходит не партикуляризм, «вера в особый путь» той или иной страны, а синтез универсализма и партикуляризма. Поиск такого синтеза, по мнению А.Турена, становится главной проблемой разработки стратегии развития той или иной страны. Это объясняется тем, что нарушение баланса между традиционностью и современностью может привести к возникновению острых социальных конфликтов. Как отмечал ученый, « ... Сегодня судьба мира зависит от того будет ли наведен мост между разумом и культурой, между современностью и идентичностью народов» [2, 7].

Синтез универсализма и партикуляризма, о котором говорит А.Турен, удалось реализовать в своей стратегии развития таким странам Востока как Япония, Корея, Сингапур, Китай и др. В данном контексте российский исследователь В.С.Лагутин отмечал, что в процессе анализа модернизации необходимо учитывать постиндустриальные особенности Востока, где реформирование происходит по-своему, заимствуя и используя научно-технические достижения Запада, обогащая их собственным вкладом и, фактически, создается новое общее поле соразвития. В процессе достижения одних и тех же целей страны Востока идут особой дорогой на основе самобытных модернистских программ развития, мобилизуя при этом собственные внутренние ресурсы. Как отмечает В.С.Лагутин, сегодня на наших глазах разрушаются восходящие еще к философии Гегеля стереотипы о пассивности, летаргичности и неспособности восточного менталитета к социально-технологическим и иным формам прогресса. Последние десятилетия показывают, что индустриализация и постиндустриализация общества может происходить в контексте различных социокультурных ценностей. Развитие стран АТР свидетельствует о том, что западные ценности следует рассматривать как одну из альтернатив развития. Необходимо отметить, что если на Западе процессы демократизации и построения социально ориентированной рыночной экономике базировались на принципах индивидуализма и рационализма, то на Востоке эти процессы основывались преимущественно на коллективистских принципах и ценностях. Сегодня всем известно что такие страны как Япония, Республика Корея, Китай вышли на пик своего развития базируясь на собственных национальных ценностях и это должно рассматриваться как образец развития стран Востока. Взаимоотношения между личностью и обществом в этих странах характеризуется стремлением сохранить себя. Они привержены сохранить прежде всего культурную идентичность. Опыт процессов модернизации в восточных странах свидетельствует о том, что здесь модернизация начинается не с либерализации государства, а с того, что государство действовало в качестве инициирующей силы проводимых реформ. Таким образом, процессы модернизации в странах Востока были детерминированы сохранением своих национальных ценностей. Здесь удалось выработать и сформировать национальную идею, объединившую большинство народов вокруг собственных национальных и культурных ценностей и включить эти страны в мировую экономическую систему. Именно сохранение своей идентичности привело к тому, что страны Востока освоили основные позитивные аспекты научно-технического прогресса стран Западной Европы и США, не вестернизируясь, при этом, в буквальном смысле слова $[3,15]$.

Необходимо отметить, что процессы модернизации в странах Востока не имеют однородный характер. Сравнительный анализ, проведенный учеными, позволяет нам сконструировать следующие модели модернизации стран Востока:

1. «Японская» модель. В этом случае необходимо говорить о странах, добившихся наиболее заметных успехов в процессе применения западного пути развития. Данные страны сближаются с западноевропейскими странами по многим параметрам. Вместе с мощной рыночной экономикой в этих странах большая роль отводится патронирующему государству. Важную значение в этой модели играют крупные транснациональные компании. Так, в Японии государство чутко реагирует на возникающие экономические затруднения, быстро и гибко принимает решения по их преодолению. Следует отметить, что Япония 
перестала быть государством традиционно восточного типа. Она превратилась в страну, которая успешно конкурирует с государствами Западной Европы и США по многим показателям развития. При всем этом, Япония не перестала быть самой собой. Опережая по многим показателям социально-экономического развития другие страны, Япония не потеряла своего лица. Это ее сила и преимущество перед многими другими странами. В этом контексте необходимо, на наш взгляд, вспомнить о дисциплине труда, отсутствии забастовок, а также удивительном гармоничном сочетании труда и капитала. Япония это яркий пример успешного синтеза современности и традиций. По пути Японии пошли и другие страны, такие, например, как Республика Корея, которая за короткий срок превратилось в развитое демократическое государство. Именно феномен синтеза партикуляризма и универсализма, на наш взгляд, является определяющим в процессе развития стран с «японской» моделью развития.

2. «Индийская» модель. Данная модель значительно отличается от первой модели своей внутренней неоднородностью. Эта модель характерна для большой группы азиатских стран, пытающихся развиваться по западному пути с разной степенью успеха, при этом до конца не перестроивших свою традиционную социальную структуру. В этих странах заметная часть населения живет уже по новому - западному образцу. В жизни этой части общества эффективно функционирует многопартийная система, демократические процедуры и другие институты демократии. Но в то же время большая часть населения по прежнему остается в плену привычного, традиционного образа жизни. Типичным представителем этой модели является Индия. Кроме того данная модель характерна для многих стран Юго-Восточной Азии (Шри-Ланка, Индонезия), а также ряд стран исламского мира (Египет, Пакистан). О многих странах этой модели заметно поступательное развитие как в социально-экономическом, так и в политическом значении. Также к этой модели относятся примыкающие страны, куда входит группа арабских нефтедобывающих государств. Здесь также существует резкий контраст населения. В отличии от стран первой группы данной модели в этих странах мало институциональных элементов западных структур, а также заметных признаков поступательного развития. Тем не менее, эти страны находятся в состоянии равновесия. Если даже экономика в этих странах не процветает, она способна обеспечить существование своих граждан.

3. «Африканская» модель. Для стран данной модели свойственно не столько развитие, сколько отставание, кризис. К этой группе относится большинство африканских государств и некоторые страны исламского мира (Афганистан, Бангладещ, Лаос, Камбоджа). Здесь также существует симбиоз традиционности и современности. Тем не менее, многие африканские страны сегодня сталкиваются с проблемами нищеты и лишь немногие страны данной модели имеют возможность перейти ко второй модели модернизации данной группы [4, 48].

Также ученые сегодня выделяют «сингапурскую» модель модернизации. «Отцом» этой модели модернизации является первый премьер-министр этой страны Ли Куан Ю, занимавший этот пост с 1959 по 1999 годы, который даже после отставки продолжал направлять работу кабинета министров в должности старшего министра правительства. Сегодня можно выделить четыре ключевых аспекта «сингапурской» модели модернизации:

1. Политическая стабильность;

2. Эффективная борьба с коррупцией;

3. Экономические реформы;

4. Социальная модернизация [5, 34].

Следует отметить, что в конце прошлого столетия на исторической сцене возникла и получила свое признание «узбекская» модель процессов модернизации и развития. Данная модель основывается на пяти принципах, которые были разработаны Президентом Узбекистана И.А.Каримовым. К ним относятся:

1. Деидеологизация экономики;

2. Государство - главный реформатор;

3. Верховенство закона;

4. Сильная социальная политика;

5. Поэтапный переход к рыночной экономике [6, 26].

Практика показала, что данная модель является успешной как в теоретическом, так и в прикладном плане. Свидетельством этого является то, что в 2014 году « ... валовой национальный продукт возрос на 8,1 процент, объем производства промышленной продукции на 8,3 процента, сельскохозяйственного производства - на 6,9 процента, капитального строительства - на 10,9 процента, розничного товарооборота - на 14,3 процента, около 70 процентов составили готовые товары с высокой добавленной стоимостью»[7].

Рассмотрев ключевые аспекты процессов модернизации в странах Востока можно прийти к следующим выводам:

1. Важным элементом успешности процессов модернизации в странах Востока является синтез традиционности и современного развития;

2. Если в странах Западной Европы и США процессы построения демократического государства с сильной социально 


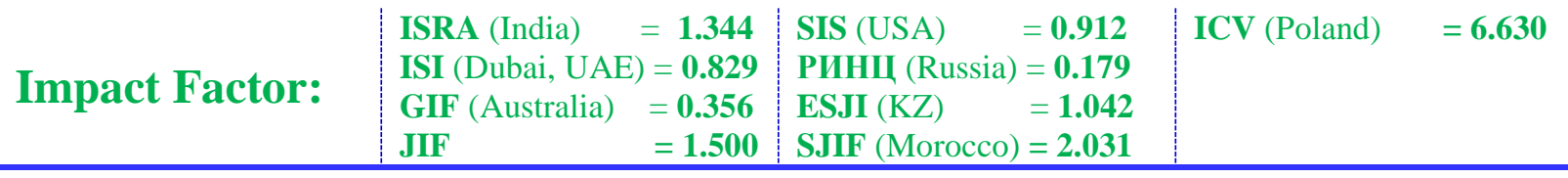

ориентированной рыночной экономики происходили на основе индивидуализма, то в странах Востока определяющую роль играла коллективистская ментальность;

3. В отличии от стран Западной Европы и США, где инициаторами процессов развития были институты гражданского общества, основной движущей силой в странах Востока были государственные институты управления;

4. Процессы модернизации в странах Востока происходят не в контексте «линии разлома» или конфликта институтов гражданского общества с государством, а в контексте доминирования государства или в форме социального партнерства:
5. Именно государство в странах Востока является ключевым определяющим звеном не только в процессе формирования стратегии социально-экономического и политического развития, но и в процессах формирования и внедрения национальной идеи, которая объединяет большинство граждан страны.

В заключении необходимо отметить, что в процессах модернизации общества в странах Востока большая роль отводится эффективному государственному управлению. Именно наличие эффективной системы государственного управления является фундаментальным условием успешной модернизации на Востоке.

\section{References:}

1. Zakarija F (2008) Postamerikanskoe budushhee. Moscow: 2008.

2. Ermahanova SA (2007) Teorija modernizacii: istorija i sovremennost'. Novosibirsk: 2007.

3. Lagutin VS (2008) Kul'turnocivilizacionnye osobennosti stran Vostoka. Moscow: 2008.

4. Shersheva NF (2003) Istorija kul'tury Vostoka. Moscow: 2003.

5. Pahomova LF (2007) Modeli procvetanija: Singapur, Malajzija, Tailand, Indonezija. Moscow: Nauka, 2007.

6. Karimov IA (1992) Uzbekistan po puti obnovlenija i progressa. T.: Uzbekiston, 1992.
7. Karimov IA (2015) Doklad na zasedanii Kabineta Ministrov Respubliki Uzbekistan, posvjashhennogo itogam social'nojekonomicheskogo razvitija strany v 2014 godu i vazhnejshim prioritetnym napravlenijam jekonomicheskoj programmy na 2015 god.

8. Karimov IA (2013) Uzbekistan na poroge XXI veka: ugrozy bezopasnosti, uslovija i garantii progressa. T.: Uzbekiston, 1997.

9. (2013) Konstitucija Respubliki Uzbekistan. T.: Uzbekiston, 2013. 40 p.

10. (2003) Ideja nacional'noj nezavisimosti: osnovnye ponjatija i principy. T.: Uzbekiston, 2003. 